Article

\title{
Evaluating Carbon Stock Changes in Forest and Related Uncertainty
}

\author{
Pasquale A. Marziliano * (D), Giuliano Menguzzato and Vittoria Coletta \\ Department of AGRARIA, Mediterranean University of Reggio Calabria, Loc. Feo Di Vito, 89165 Reggio \\ Calabria, Italy; gmenguzzato@unirc.it (G.M.); vittoria.coletta@unirc.it (V.C.) \\ * Correspondence: pasquale.marziliano@unirc.it; Tel.: +39-965-169-4256
}

Received: 15 September 2017; Accepted: 19 September 2017; Published: 22 September 2017

\begin{abstract}
For the evaluation of changes in the carbon stock of living biomass, two methods are reported in the Good Practice Guidance for Land Use, Land-Use Change, and Forestry: (1) the default method, which requires the biomass carbon loss to be subtracted from the biomass carbon increment for the reporting year; and (2) the stock change method, which requires two consecutive biomass carbon stock inventories for a given forest area at two points in time. We used three methods to estimate above-ground biomass: (1) application of allometric equations, (2) constant BEF (biomass expansion factor), and (3) age-dependent BEF, following which we evaluated the changes in carbon stock and the related uncertainty. Our study was carried out in a Douglas fir plantation composed of plots with three different planting densities, monitored at three different ages $(15,25$, and 40 years old). Results showed the highest uncertainty in the estimates based on the constant BEF, whereas the use of allometric equations led to the lowest uncertainty in the estimates. With a constant BEF, it is usually difficult to obtain a reliable value for the whole tree biomass because stem proportion increases with tree size at the expense of the other components. The age-dependent BEFs aim to reduce the bias representing the actual change in stock, thus we found a lower uncertainty in the estimates by using this method compared to the constant BEF. The default method had the highest uncertainty (35.5-48.1\%) and gave an estimate higher by almost double compared to the stock change method, which had an uncertainty ranging from $2.9 \%$ (estimated by the allometric equation) to $3.4 \%$ (estimated by the constant BEF).
\end{abstract}

Keywords: carbon stock; uncertainty; Douglas fir; allometric equation; BEF

\section{Introduction}

According to environmental conditions, development stages, and management regimes, forests can sequester atmospheric carbon to mitigate climate change. The degree of carbon sequestration depends on environmental controls, and has been a topic of considerable interest in plant ecology for decades [1]. The combined effects of logging and forest regrowth on abandoned land are responsible for $10-25 \%$ of global human-induced emissions [2,3].

Estimation of carbon stocks at scales ranging from local to global is crucial for accurately predicting future changes in atmospheric carbon dioxide [4]. Information related to the carbon stocks can be achieved, amongst others, through destructive methods, by harvesting trees to calculate biomass in tree components (stem, foliage, roots) and then building regressions for further estimates $[5,6]$. So far, few allometric equations are available across the globe; they are mainly for above-ground compartments, and are largely species- and site-specific. In cases where these are not available, biomass is normally estimated using biomass expansion factors (BEFs) that use estimated timber volume in combination with other stand-level variables to estimate plot-level biomass [7]. A biomass expansion factor can be constant (e.g., from the National Inventory database), or it can be function of 
a stand characteristic (i.e., dimensions of the median tree of a stand, merchantable stem volume, or stand age) [8,9]. Investigation and quantification of tree biomass forms the basis of estimates of forest carbon pools and is therefore directly linked to some of the mechanisms for carbon offsetting and sequestration enshrined in the Kyoto protocol [10]. Accurate estimates of forest biomass are necessary since, as a Party to both the United Nations Framework Convention on Climate Change (UNFCCC) and its Kyoto Protocol, replaced in 2015 by the Paris Protocol, the European Community has to submit its annual GHG (greenhouse gases) inventory. In the second commitment period, which is ongoing, Parties must reduce GHG emissions by at least 18\% below 1990 levels in the eight-year period from 2013 to 2020 . Under these agreements $[11,12]$ it has become necessary to develop methods to estimate changes in carbon stocks and how these pools will change as a result of management [13]. However, substantial uncertainties remain in current model estimates of terrestrial carbon, and there is an increasing need to quantify and reduce these uncertainties [14,15]. Uncertainty arises from the inability to perfectly measure key variables, the necessary use of models to make predictions, and the natural variability of ecosystem processes across the landscape [16]. According to the Intergovernmental Panel on Climate Change (IPCC) good practice guidance, the national reporting of changes of $\mathrm{CO}_{2}$ equivalents in forest and other woody biomass stocks can be calculated by a default method as the difference between growth and drain estimated by considering all relevant processes (the growth of trees and carbon losses due to harvest, natural mortality, and natural disturbances), or by the stock change method as the change in stocks between two consecutive inventories. Information on the major uncertainties involved in the calculations of forest carbon stocks and stock changes is needed in the negotiations of the Climate Convention.

The main aims of this study were: (i) to carry out a plot-based estimate of carbon stock and carbon stock change in a Douglas fir stand by using three biomass estimate models, according to three different planting densities $(1667,2000$, and 2500 trees per hectare) and at three ages $(15,25$, and 40 years old); and (ii) to quantify uncertainty in the carbon stock and carbon stock change estimates. Plot-based estimates of forest carbon stocks and carbon fluxes are derived metrics that contain multiple sources of uncertainty [17-19].

Carbon stock was calculated from biomass estimated with three different methods: (1) with constant biomass expansion factors (BEFs), (2) with age-dependent BEFs, and (3) with biomass equations applied directly to tree-wise data of the sample plots. The changes in carbon stock were therefore evaluated with the two methods suggested by the IPCC. The related uncertainty differs between the two methods since "the uncertainties in the default method are dominated by model errors due to the different components which only partly are usually derived from statistical forest inventory data, whereas the uncertainties in the stock change method, which are derived from net-carbon changes based on repeated statistical forest inventories, are dominated by the sampling error, especially in cases where the net-carbon changes are very small" [20]. Many studies have tended to focus on uncertainty in carbon stock estimates, rather than uncertainty in carbon change over time, but carbon change is arguably the most important of the two metrics, as it is the basis for UNFCCC reporting [21].

\section{Materials and Methods}

\subsection{Study Area}

The study area $\left(39^{\circ} 25^{\prime} \mathrm{N}, 16^{\circ} 2^{\prime} \mathrm{E}\right)$ is located in the northern coastal chain of Calabria, in the Tyrrhenian side of south Italy. The climate of the area is typical Mediterranean. The annual rainfall is $1233 \mathrm{~mm}$, with the minimum precipitation in summer $(88 \mathrm{~mm})$ and the maximum during the winter $(501 \mathrm{~mm})$. The average annual temperature is $11.5^{\circ} \mathrm{C}$ at an altitude of $950 \mathrm{~m}$ a.s.l.

This area is the property of the Regional Italian State Forestry Agency and, in 1967, Douglas fir (Pseudotsuga menziesii, (Mirb.) Franco) was extensively used to reforest the whole of the property. The plantation was part of a reforestation project carried out in the south of Italy with funding earmarked by the national government to restore forest ecosystems in abandoned agriculture areas [22]. 
The plantation was executed with differing planting densities [23]. The sample plots considered for the carbon stock estimates are within the Douglas fir plantation. In this study, we estimated carbon stocks of 2500, 2000, and 1667 trees ha $^{-1}$ densities at ages of 15, 25, and 40 years. Therefore, nine permanent plots were established (three for each planting density). Each plot had a square shape, with a surface area of $900 \mathrm{~m}^{2}$. In each plot, the diameters at breast height (DBH) of all trees were measured. In addition, the total height $(\mathrm{H})$ of a representative sample (about $50 \%$ ) of trees was measured.

\subsection{Carbon Stock and Stock Change Estimates and Uncertainty Analysis}

We applied three methods for biomass estimates, at the individual tree level:

1. The stem volume was estimated with a volume equation for Douglas fir from the National Italian Forest Inventory [24], and then multiplied by a constant biomass expansion factor $\left(\mathrm{Mg} \mathrm{m}^{-3}\right)$ reported by the IPCC [12] for Douglas fir (Table 1).

2. The stem volume was estimated with a volume equation for the Douglas fir plantation in Calabria [25], and then multiplied by an age-dependent BEF elaborated for the Douglas fir in Calabria [22] (Table 1).

3. The above-ground biomass was estimated with allometric equations for Douglas fir in Calabria [25] (Table 1).

Table 1. Equations used in this study.

\begin{tabular}{lcc}
\hline \multicolumn{1}{c}{ Equation Name } & Equation Expression & Equation \\
\hline $\begin{array}{l}\text { Volume equation for Douglas fir from the } \\
\text { National Italian Forest Inventory (INFC) }\end{array}$ & $V=-7.9946+0.0333 \cdot D B H^{2} \cdot H+1.2186 \cdot D B H$ & $(1)$ \\
\hline $\begin{array}{l}\text { A constant BEF from the INFC for conifer } \\
\text { plantations in Italy }\end{array}$ & BEF $=1.41$ \\
\hline $\begin{array}{l}\text { Volume equation for the Douglas fir } \\
\text { plantation in Calabria }\end{array}$ & $V=-13.1172+0.6327 \cdot D B H^{2}$ & $(3)$ \\
\hline Age-dependent BEF equations elaborated for & $B E F_{2500}=2.099 \cdot A G E^{-0.408}$ \\
Douglas fir in Calabria & $B E F_{2000}=2.088 \cdot A G E^{-0.381}$ & $(4)$ \\
\hline & $B E F_{1667}=1.923 \cdot A G E^{-0.356}$ & $(5)$ \\
Allometric equations for Douglas fir in & $W_{2500}=-22.76+0.49 \cdot D B H^{2}$ & \\
Calabria & $W$ & $2000=-33.40+0.56 \cdot D B H^{2}$ \\
\end{tabular}

Notes: $V$ is stem volume $\left(\mathrm{dm}^{3}\right.$ in Equation (1), $\mathrm{m}^{3}$ in Equation (3)), DBH is the diameter at breast height $(\mathrm{cm}), \mathrm{H}$ is the height of tree $(\mathrm{m}), \mathrm{BEF}$ is biomass expansion factor $\left(\mathrm{Mg} \mathrm{m}^{-3}\right)$, AGE is age of stand (years), $\mathrm{W}$ is above-ground biomass of tree $(\mathrm{kg})$.

Diameter at breast height $(\mathrm{DBH})$ and total height were used as independent variables in the volume and biomass equations.

The reference values for the biomass of Douglas fir in Calabria are the allometric equations by Menguzzato and Tabacchi [25].

As suggested by the IPCC [11], for all of the models used (volume and allometric equations as well as expansion factors), the associated relative standard error (RSE) was calculated with the method of error propagation equations. Having applied biomass and volume equations to tree-wise data of the sample plots directly, we could consider that the components of the errors accounted for were the sampling and model errors (assumed to be small). For the BEF-based method, the sampling error in the stem volume estimate and the error of the BEFs were accounted for. It was not possible to assess the error associated with the constant $\mathrm{BEF}$, since the literature from which it has been drawn [12] does not provide quantitative uncertainty estimates, whereas we could combine the error of the age-dependent BEFs with the sampling error for the stem volume of sample plots by density classes to obtain the RSE 
of the tree biomass stock in a given density class. Then, the RSE of the overall biomass estimate of trees was estimated using the following equation [26]:

$$
r_{\text {tot }}=\frac{\sqrt{\left(r_{\text {stock }, 1} \cdot W_{1}\right)^{2}+\left(r_{\text {stock }, 2} \cdot W_{2}\right)^{2}+\ldots\left(r_{\text {stock }, n} \cdot W_{n}\right)^{2}}}{\left|W_{1}+W_{2}+\ldots W_{n}\right|}
$$

where $r_{\text {tot }}$ is the relative standard error of the total biomass (the sum of all age classes), $W_{i}$ is the biomass stock in age-class $i$, and $r_{\text {stock, } i}$ is the relative standard error of the biomass stock in age-class $i$.

The carbon stock at ages 15,25 , and 40 years for the sample plots of any density class was calculated using the approximation that the mass of woody parts contain $\sim 50 \%$ carbon [27].

The step subsequent to the estimate of the biomass (and therefore of the carbon), for the three methods described above, was the evaluation of the change in the carbon stock that occurred in 10 years with both the default method (also called "growth and drain") and the stock change method. In order to reduce the bias when using the stock change method, it is necessary that BEFs reflect the actual change in stock by incorporating the accumulation of growth per tree fraction, with the effects of harvest and natural thinning patterns in one constant [9]. The method of age-dependent BEFs enables the ratio of whole tree biomass to stem volume to change with tree size. The default method is inevitably linked to a large bias, which originates when both growth and drain are converted from volume to biomass; we could reduce this bias by deriving separate age-dependent BEFs for growth and harvest. The uncertainty of stock change associated with both methods was estimated using Equation (7) [28]:

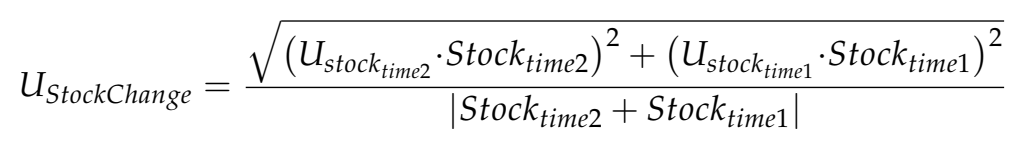

where $U_{\text {StockChange }}$ is the percentage of uncertainty of the stock change, $U_{\text {stocktime } i}$ is the percentage of uncertainty associated with time $i$, and Stock $_{\text {time }} i$ is the emission/removal estimate for time $i$.

\section{Results}

The reference values for the biomass of Douglas fir in Calabria are the allometric equations by Menguzzato and Tabacchi [25]. We chose to use these equations built for a Douglas fir plantation in the same environmental conditions but with different dendrometric characteristics. This choice is due to the fact that the allometric equations built in 1986 have been included in all international databases [29], therefore they are easy to access and they are the most-used reference for Douglas fir above-ground biomass estimates in Mediterranean Italy. Table 2 shows the reliability of the carbon estimates obtained with the three alternative models. On average, allometric equations $\left(\mathrm{W}_{3}\right)$ estimated an above-ground carbon stock of $67.1 \mathrm{Mg} \mathrm{ha}^{-1}, 117 \mathrm{Mg} \mathrm{ha}^{-1}$, and $148.1 \mathrm{Mg} \mathrm{ha}^{-1}$ at age 15, 25, and 40 years, respectively. At the age of 15 years, compared to the allometric equations, the method of age-dependent BEF $\left(\mathrm{W}_{2}\right)$ estimated a higher total above-ground carbon stock $\left(81 \mathrm{Mg} \mathrm{ha}^{-1}\right)$ (Table 2$)$, whereas the method of volume from the National Italian Forest Inventory (INFC) and the constant BEF $\left(\mathrm{W}_{1}\right)$ estimated a lower value $\left(58.1 \mathrm{Mg} \mathrm{ha}^{-1}\right)$. Moreover, significant differences were found between the three biomass models $(p<0.001)$ and between planting densities; the 1667 class was found to be significantly different from the others $(p=0.003)$. At the age of 25 years, the $W_{1}$ model gave the highest estimate $\left(149.5 \mathrm{Mg} \mathrm{ha}^{-1}\right)$; we did not find significant differences between planting densities and the $\mathrm{W}_{3}$ model only differed from the others methods $(p=0.002)$. Compared to the allometric equations, the age-dependent BEFs overestimated carbon stock at all ages, whereas the constant BEF underestimated it at 15 years, and overestimated it at 25 and 40 years. At the age of 40 years, the $\mathrm{W}_{1}$ model, compared to the allometric model, estimated almost double the carbon $\left(260.2 \mathrm{Mg} \mathrm{ha}^{-1} \mathrm{vs.} 148.1 \mathrm{Mg} \mathrm{ha}^{-1}\right)$; all the methods differed with statistical significance $(p<0.001)$ and differences were found between the three planting densities $(p=0.001)$. 
Table 2. Above-ground biomass estimates and relative differences in biomass estimates with the three methods. $\mathrm{W}_{1}$ : above-ground biomass estimated using the constant $\mathrm{BEF}$ and volume equation from the INFC; $\mathrm{W}_{2}$ : above-ground biomass estimated using the age-dependent BEF and volume equation for the Douglas fir plantation in Calabria; $\mathrm{W}_{3}$ : above-ground biomass estimated using the allometric equations for the Douglas fir in Calabria.

\begin{tabular}{|c|c|c|c|c|c|c|}
\hline \multicolumn{7}{|c|}{ Above-Ground Carbon Estimates } \\
\hline Age (Years) & $\begin{array}{c}\text { Density } \\
\text { Classes } \\
\text { (Trees ha }^{-1} \text { ) }\end{array}$ & $\begin{array}{c}\mathrm{W}_{1} \\
\left(\mathrm{Mg} \mathrm{ha}^{-1}\right)\end{array}$ & $\begin{array}{c}\mathrm{W}_{2} \\
\left(\mathrm{Mg} \mathrm{ha}^{-1}\right)\end{array}$ & $\begin{array}{c}\mathrm{W}_{3} \\
\left(\mathrm{Mg} \mathrm{ha}^{-1}\right)\end{array}$ & $\begin{array}{l}\text { Average } \\
\left(\mathrm{Mg} \mathrm{ha}^{-1}\right)\end{array}$ & $\begin{array}{c}\text { ANOVA Planting } \\
\text { Density }\end{array}$ \\
\hline \multirow[t]{3}{*}{15} & 2500 & 60.9 & 84.2 & 70.2 & $71.8 A$ & \\
\hline & 2000 & 59.4 & 85.0 & 70.0 & $71.5 A$ & $\mathrm{~F}=36.3 ; p=0.003$ \\
\hline & 1667 & 53.9 & 73.8 & 61.0 & $62.9 B$ & \\
\hline \multirow[t]{2}{*}{$\begin{array}{c}\text { ANOVA Models } \\
\mathrm{F}=191.2 ; p \leq 0.001\end{array}$} & Average & 58.1 & 81.0 & 67.1 & & \\
\hline & & $A$ & $B$ & $\mathrm{C}$ & & \\
\hline \multirow[t]{3}{*}{25} & 2500 & 146.4 & 137.9 & 114.6 & $133.0 \mathrm{~A}$ & \\
\hline & 2000 & 146.4 & 144.9 & 120.5 & $137.3 A$ & $\mathrm{~F}=1.02 ; p=0.438$ \\
\hline & 1667 & 155.7 & 139.4 & 116.0 & $137.0 \mathrm{~A}$ & \\
\hline \multirow[t]{2}{*}{$\begin{array}{l}\text { ANOVA Models } \\
\mathrm{F}=49.2 ; p=0.002\end{array}$} & Average & 149.5 & 140.7 & 117.0 & & \\
\hline & & $A$ & $A$ & $B$ & & \\
\hline \multirow[t]{3}{*}{40} & 2500 & 258.9 & 170.5 & 142.5 & $190.6 A$ & \\
\hline & 2000 & 291.8 & 204.6 & 170.8 & $222.4 B$ & $\mathrm{~F}=51.3 ; p=0.001$ \\
\hline & 1667 & 230.0 & 156.8 & 131.0 & $172.6 \mathrm{C}$ & \\
\hline \multirow{2}{*}{$\begin{array}{l}\text { ANOVA Models } \\
\mathrm{F}=272.9 ; p \leq 0.001\end{array}$} & Average & 260.2 & 177.3 & 148.1 & & \\
\hline & & $A$ & $B$ & $C$ & & \\
\hline
\end{tabular}

In general, the RSE (\%) of carbon stock was higher in the lowest planting density and at the age of 15 years (Figure 1 ).

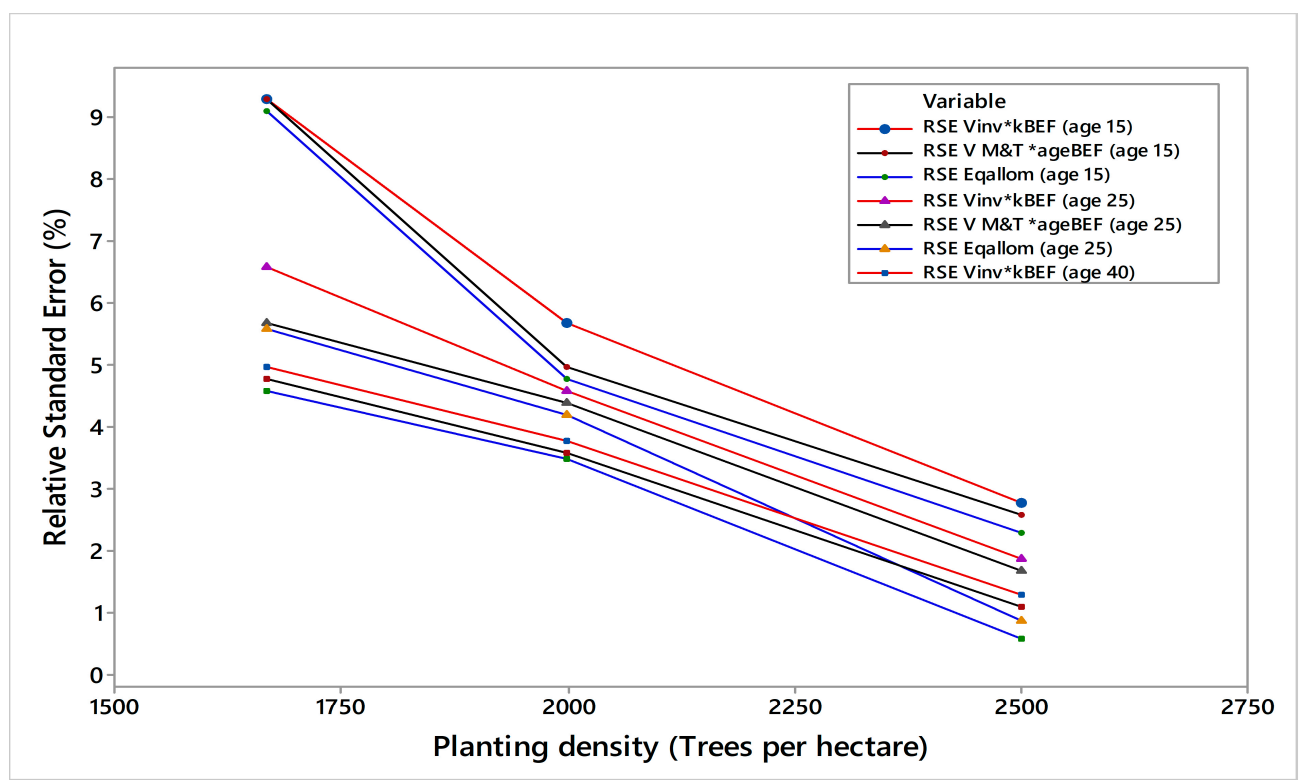

Figure 1. RSE (\%) of carbon stock estimates with the three methods according to density classes at ages 15 and 25. Vinv*kBEF: carbon stock estimated from biomass calculated with the first method; V M\&T*ageBEF: carbon stock estimated from biomass calculated with the second method; Eqallom: carbon stock estimated from biomass calculated with the third method. 
For each age, two-way analysis of variance (independent variables: planting density and biomass models) showed very significant differences in planting density and significant differences in biomass models. The lowest RSE was found with the 2500 trees/ha density class (on average $2.6 \%$ at 15 years, $1.5 \%$ at 25 years, and $1.03 \%$ at 40 years), with significant differences between all planting densities. Moreover, the RSE significantly increased when the planting density decreased (Figure 1).

The lowest RSE was found when allometric equations were used (on average $5.4 \%$ at 15 years, $3.6 \%$ at 25 years, and $3.0 \%$ at 40 years), whereas the estimates by the volume equation from the INFC and the constant BEF generated the highest RSE (5.9\% at 15 years, $4.4 \%$ at 25 years, and $3.7 \%$ at 40 years). At the age of 25 and 40 years, the RSEs calculated with the $\mathrm{W}_{3}$ model (allometric equation) and the $\mathrm{W}_{1}$ model (volume equation from the INFC and constant BEF) were significantly different, whereas no significant difference was found with the $\mathrm{W}_{2}$ model (age-dependent BEF and volume equation for the Douglas fir). At the age of 15 years, no significance difference was found between the three methods. However, the $p$ value seemed to decrease when age increased $(0.081,0.052$, and 0.025 , respectively, at the age of 15,25 , and 40 years) Also, uncertainty related to the estimate of biomass was lower when using the allometric equations (Table 3).

Table 3. Relative standard errors (RSE) of biomass estimates according to density classes and uncertainty $(\mathrm{U} \%)$ averaged by density class. $\mathrm{W}_{1}$ : above-ground biomass estimated using the constant BEF and volume equation from the INFC; $\mathrm{W}_{2}$ : above-ground biomass estimated using the age-dependent BEF and volume equation for the Douglas fir plantation in Calabria; $\mathrm{W}_{3}$ : above-ground biomass estimated using the allometric equations for Douglas fir in Calabria.

\begin{tabular}{|c|c|c|c|c|c|c|}
\hline \multicolumn{7}{|c|}{ RSE of Biomass Estimates } \\
\hline Age (Years) & $\begin{array}{l}\text { Density Classes } \\
\text { (Trees ha }^{-1} \text { ) }\end{array}$ & $W_{1}(\%)$ & $\mathrm{W}_{2}(\%)$ & $\mathrm{W}_{3}(\%)$ & Average & $\begin{array}{l}\text { ANOVA Planting } \\
\text { Density }\end{array}$ \\
\hline \multirow[t]{3}{*}{15} & 2500 & 2.8 & 2.6 & 2.3 & $2.6 A$ & \\
\hline & 2000 & 5.7 & 5.0 & 4.8 & $5.2 B$ & $\mathrm{~F}=791.79 ; p \leq 0.0001$ \\
\hline & 1667 & 9.3 & 9.3 & 9.1 & $9.2 \mathrm{C}$ & \\
\hline \multirow[t]{2}{*}{$\begin{array}{l}\text { ANOVA Models } \\
\mathrm{F}=5.013 ; p=0.081\end{array}$} & Average & 5.9 & 5.6 & 5.4 & & \\
\hline & & $A$ & $A$ & $A$ & & \\
\hline \multirow[t]{3}{*}{25} & 2500 & 1.9 & 1.7 & 0.9 & $1.5 A$ & \\
\hline & 2000 & 4.6 & 4.4 & 4.2 & $4.4 B$ & $\mathrm{~F}=216.67 ; p \leq 0.0001$ \\
\hline & 1667 & 6.6 & 5.7 & 5.6 & $6.0 \mathrm{C}$ & \\
\hline \multirow[t]{2}{*}{$\begin{array}{c}\text { ANOVA Models } \\
\mathrm{F}=6.766 ; p=0.052\end{array}$} & Average & 4.4 & 3.9 & 3.6 & & \\
\hline & & $A$ & $A B$ & $B$ & & \\
\hline \multirow[t]{3}{*}{40} & 2500 & 1.4 & 1.1 & 0.6 & $1.0 \mathrm{~A}$ & \\
\hline & 2000 & 3.9 & 3.6 & 3.5 & $3.7 B$ & $\mathrm{~F}=379.18 ; p \leq 0.0001$ \\
\hline & 1667 & 5.9 & 5.1 & 4.9 & $5.3 \mathrm{C}$ & \\
\hline \multirow[t]{2}{*}{$\begin{array}{c}\text { ANOVA Models } \\
\mathrm{F}=11.273 ; p=0.023\end{array}$} & Average & 3.7 & 3.3 & 3.0 & & \\
\hline & & $A$ & $A B$ & $B$ & & \\
\hline \multicolumn{7}{|c|}{ U (\%) of biomass estimates (Average by density classes) } \\
\hline 15 & & 7.3 & 6.8 & 6.7 & & \\
\hline 25 & & 5.8 & 5.0 & 4.7 & & \\
\hline 40 & & 4.9 & 4.2 & 3.6 & & \\
\hline
\end{tabular}

The stock change method was applied to data from two inventories (at the ages of 15 and 40 years). The application with the allometric equations gave an estimate of carbon stock variation of 3.2 $\mathrm{MgCha}{ }^{-1} \mathrm{y}^{-1}$. By using the volume from the INFC and the constant BEF, the highest stock change was estimated (8.1 $\mathrm{MgC} \mathrm{ha}^{-1} \mathrm{y}^{-1}$ ). Lower densities showed higher carbon increments. The uncertainty 
$(\mathrm{U} \%)$ associated with all of the combined models was low, with the lowest $\mathrm{U} \%$ for estimates found by the allometric equations (2.9\%) (Figure 2a).

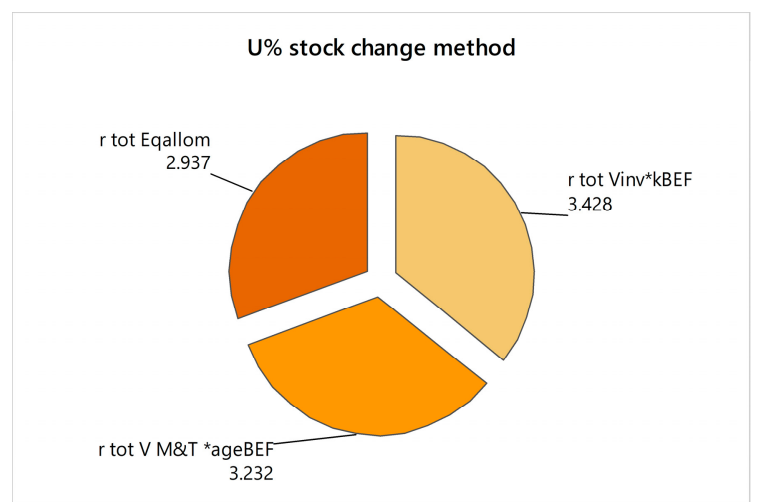

(a)

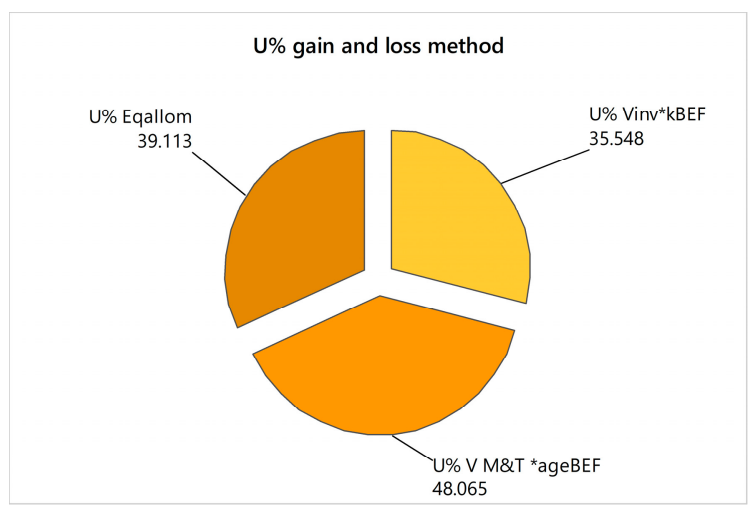

(b)

Figure 2. The uncertainty (U\%) associated with all of the combined models for (a) the stock change method and (b) the default method.

In order to apply the default method, estimates of both annual losses and growth are needed; thus, all components of the drain (losses), such as natural mortality, fuelwood gathering, and logging, as well as growth on an annual basis should be quantifiable. Since the plots under study are part of a permanently monitored area, mortality and current increment data were available. The default method applied with the three methods gave a carbon change estimate ranging between 4.9 and $5.9 \mathrm{Mg} \mathrm{C} \mathrm{ha} \mathrm{y}^{-1} \mathrm{y}^{-1}$ (Figure 3), about $41 \%$ higher than the stock change method. Also, for all of the methods, the related U\% was very high (35.5-48.1\%) Figure $2 \mathrm{~b}$. This can be explained by the cumulative model errors that originated from the separate estimates of drain and losses from mortality and increment data.

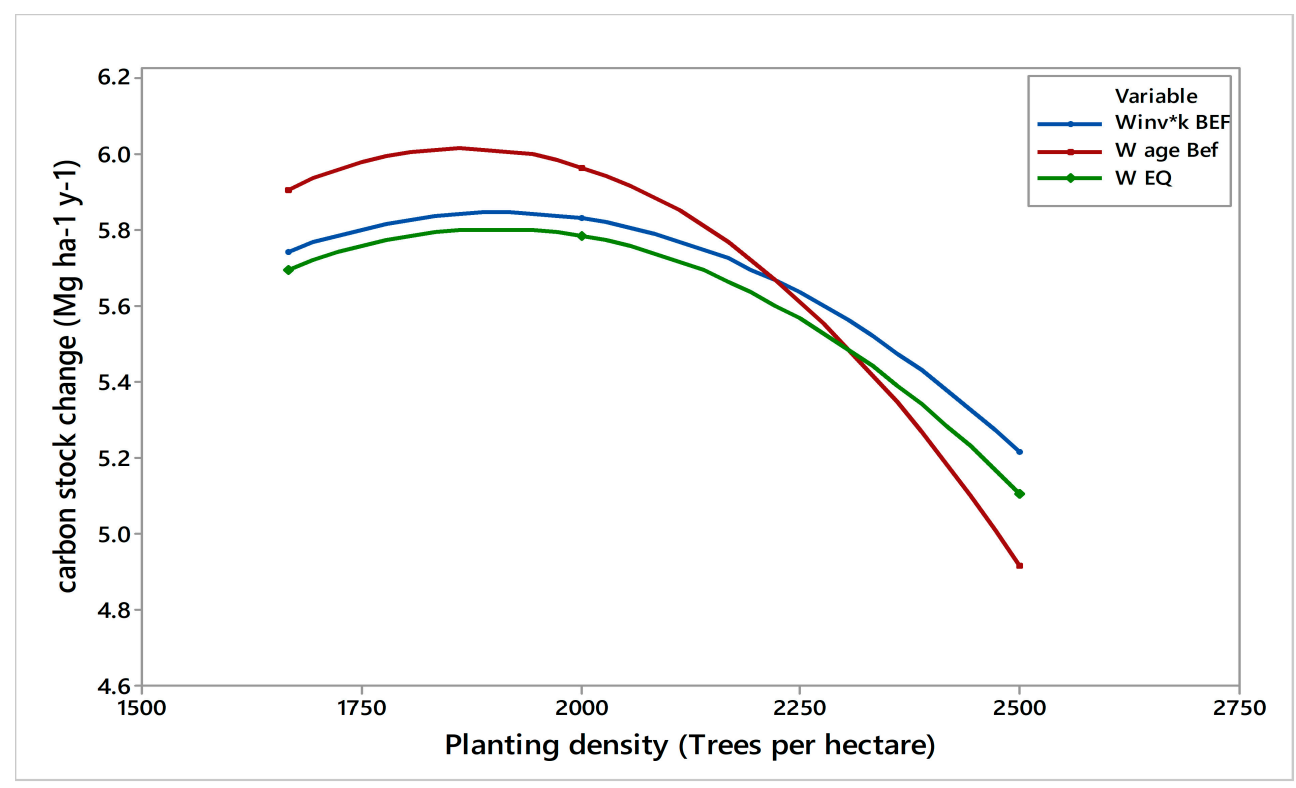

Figure 3. Carbon stock change estimated with the default method, considering all three methods used for biomass estimates. Winv ${ }^{*} \mathrm{kBEF}$ : carbon stock estimated from biomass calculated with the first method; W age BEF: carbon stock estimated from biomass calculated with the second method; W EQ: carbon stock estimated from biomass calculated with the third method. 


\section{Discussion}

The error imputable to the choice of allometric model to estimate carbon stock is considered to be of crucial importance [21,30-33]. We found higher uncertainty when estimating above-ground carbon stock and carbon stock changes of trees with the constant tree species-specific BEF, compared to the allometric equations. BEFs require the estimation of wood volumes, followed by the application of expansion factors to account for non-inventoried tree components, leading to an increase of sources of error by stepping from one calculation to another [34,35]. When using a constant BEF, a reliable value for the whole tree biomass is not achievable because stem proportion increases with tree size at the expense of other tree components. The age-dependent BEFs are useful to reduce the bias, because the actual change in stock can be accounted for. We therefore suggest using age-dependent BEFs based on regionally representative sampling, in order to account for both model and sampling errors. In any case, the uncertainty in the conversion from tree volume to carbon content is one of the major gaps in carbon accounting at regional and national levels, together with the shortage of quantitative uncertainty analysis [36,37]. The relative accuracy of all of the methods depends on the underlying data used to derive the allometric model or the ratio of volume to biomass. Pelletier et al. [21] illustrated this point by using two allometric equations on the same inventory data; they found different results, proving that allometric models are another important source of uncertainty in the quantification of emissions from land-cover change. Planting density and age strongly affect tree allometry; thus, the accuracy of biomass estimates strictly depends on the sample trees used for the construction of regression relationships. Estimates are given with higher uncertainty when the dendrometric characteristics of stands under estimation differ from those of the sample plots used for model calibration.

The overall error occurring with use of these constant BEFs cannot be assessed, but in almost all European countries, constant BEFs are applied without quantitative uncertainty.

It is important to carefully evaluate the applicability of the available BEFs before they are used in national inventories. For example, in Finland, uncertainty was evaluated for 1990-2010 biomass C stock uncertainty (with results ranging from $2 \%$ to $5 \%$ ), with an uncertainty of the biomass $C$ stock change ranging between $11 \%$ and $27 \%$, depending on the size of the change. It was shown that when the biomass $C$ stock change was low, the uncertainty was higher, while a large $C$ stock change resulted in a lower uncertainty. When accounting for carbon stock at the national level, the positive and negative differences could be balanced, and the overall difference in above-ground biomass between tree-wise estimates and age-dependent BEFs can be even lower.

The IPCC [11] suggests utilizing BEFs for the stock change method, which might be very sensitive when large stocks are used to detect small changes. In our study, we found a low uncertainty related to stock changes estimated with age-dependent BEFs. We found lower uncertainties when using the stock change method compared to the default method due to cumulative model errors that originated from the separate estimates of drain and losses from mortality and increment data, even though-according to Cienciala et al. [38] — the default method may represent a more attractive solution as compared to the stock change method, because it discerns emissions by removals (increment) and sources (harvest and other loss), whereas the stock change method gives only the net change of emissions associated with forest biomass. However, for the application of the default method, more information must be known (increment, the estimation of which currently depends on growth and yield tables); therefore, the stock change method might represent a more objective and less uncertain approach.

\section{Conclusions}

Reliable uncertainty estimates are needed to improve research findings aimed at the assessment of the importance of emission sources and carbon sinks and the development of greenhouse gas inventories. Our results confirm the need for long-term monitoring of the ecosystem using permanent sample plots, to evaluate inter-annual variation that can be represented in the carbon accounting estimates. Governments should recognize the potential value of developing good national forest 
carbon monitoring systems under the UNFCCC, and the IPCC could give the means to stimulate continuous progress on the incorporation of uncertainty analyses and on the mitigation of the main sources of error in the quantification of emissions from land-cover change, particularly in forest carbon stock estimates [21].

Acknowledgments: We aknowledge all the University collaborators who gave their support for the preparation of this paper. We also thank the Department of Agraria of Mediterannean University for funding our research study. We would like to thank the three anonymous reviewers for their suggestions and comments that greatly improved the manuscript.

Author Contributions: Pasquale A. Marziliano mainly performed the analyses, prepared the input data and contributed to the introduction and discussion of the results; Vittoria Coletta was responsible for drafting the paper and contributed to the discussion of the results; Giuliano Menguzzato contributed to review the main contents.

Conflicts of Interest: The authors declare no conflict of interest.

\section{References}

1. Reichstein, M.; Ciais, P.; Papale, D.; Valentini, R.; Running, S.; Viovy, N.; Cramer, W.; Granier, A.; Ogée, J.; Allard, V.; et al. Reduction of ecosystem productivity and respiration during the European summer 2003 climate anomaly: A joint flux tower, remote sensing and modeling analysis. Glob. Chang. Biol. 2007, 13, 634-651. [CrossRef]

2. Achard, F.; Eva, H.D.; Stibig, H.; Mayaux, P.; Gallego, J.; Richards, T.; Malingreau, J. Determination of deforestation rates of the world's humid tropical forests. Science 2002, 297, 999-1002. [CrossRef] [PubMed]

3. Gullison, R.E.; Frumhoff, P.C.; Canadell, J.G.; Field, C.B.; Nepstad, D.C.; Hayhoe, K.; Avissar, R.; Curran, L.M.; Friedlingstein, P.; Jones, C.D.; et al. Tropical forests and climate policy. Science 2007, 316, 985-986. [CrossRef]

4. Yu, G.R.; Chen, Z.; Piao, S.L.; Peng, C.H.; Ciais, P.; Wang, Q.F.; Li, X.R.; Zhu, X.J. High carbon dioxide uptake by subtropical forest ecosystems in the East Asian monsoon region. Proc. Natl. Acad. Sci. USA 2014, 111, 4910-4915. [CrossRef]

5. Sanesi, G.; Lafortezza, R.; Colangelo, G.; Marziliano, P.A.; Davies, C. Root system investigation in sclerophyllous vegetation: An overview. Ital. J. Agron. 2013, 8, 121-126. [CrossRef]

6. Marziliano, P.A.; Lafortezza, R.; Medicamento, U.; Lorusso, L.; Giannico, V.; Colangelo, C.; Sanesi, G. Estimating belowground biomass and root/shoot ratio of Phillyrea latifolia L. in the Mediterranean forest landscapes. Ann. For. Sci. 2015, 72, 585-593. [CrossRef]

7. Tobin, B.; Nieuwenhuis, M. Biomass expansion factors for Sitka spruce (Picea sitchensis (Bong) Carr.) in Ireland. Eur. J. For. Res. 2007, 126, 189-196. [CrossRef]

8. Lehtonen, A.; Mäkipää, R.; Heikkinen, J.; Sievänen, R.; Liski, J. Biomass expansion factors (BEF) for Scots pine, Norway spruce and birch according to stand age for boreal forests. For. Ecol. Manag. 2004, 188, 211-224. [CrossRef]

9. Petersson, H.; Holm, S.; Ståhl, G.; Alger, D.; Fridman, J.; Lethonen, A.; Lundstrøm, A.; Mäkipää, R. Individual tree biomass functions or biomass expansion factors for assessment of carbon stock changes in living biomass-A comparative study. For. Ecol. Manag. 2012, 270, 78-84.

10. Pajtik, J.; Konopka, B.; Lukac, M. Biomass functions and expansion factors in young Norway spruce (Picea abies [L.] Karst) trees. For. Ecol. Manag. 2008, 256, 1096-1103.

11. Intergovernmental Panel on Climate Change. Good Practice Guidance for Land Use, Land-Use Change and Forestry; Penman, J., Gytarsky, M., Hiraishi, T., Kruger, D., Pipatti, R., Buendia, L., Miwa, K., Ngara, T., Tanabe, K., Wagner, F., Eds.; IPCC/IGES: Hayama, Japan, 2003.

12. (Intergovernmental Panel on Climate Change). 2006 IPCC Guidelines for National Greenhouse Gas Inventories; Eggleston, H.S., Buendia, L., Miwa, K., Ngara, T., Tanabe, K., Eds.; Prepared by the National Greenhouse Gas Inventories Programme; IGES: Hayama, Japan, 2006.

13. Mund, M.; Kummetz, E.; Hein, M.; Bauer, G.A.; Schulze, E.D. Growth and carbon stocks of a spruce forest chronosequence in central Europe. For. Ecol. Manag. 2002, 171, 275-296. [CrossRef]

14. Barman, R.; Jain, A.K.; Liang, M.L. Climate-driven uncertainties in modeling terrestrial gross primary production: A site level to global-scale analysis. Glob. Chang. Biol. 2014, 20, 1394-1411. [CrossRef] [PubMed]

15. Ahlstroem, A.; Schurgers, G.; Arneth, A.; Smith, B. Robustness and uncertainty in terrestrial ecosystem carbon response to CMIP5 climate change projections. Environ. Res. Lett. 2012, 7, 044008. [CrossRef] 
16. Bolker, B. Ecological Models and Data in R; Princeton University Press: Princeton, NJ, USA, 2008.

17. Phillips, O.L.; Malhi, Y.; Higuchi, N.; Laurance, W.F.; Nunez, P.V.; Vasquez, R.M.; Laurance, S.G.; Ferreira, L.V.; Stern, M.; Brown, S.; et al. Changes in the carbon balance of tropical forests: Evidence from long-term plots. Science 1998, 282, 439-442. [CrossRef] [PubMed]

18. Chave, J.; Condit, R.; Muller-Landau, H.C.; Thomas, S.C.; Ashton, P.S.; Bunyavejchewin, S.; Co, L.L.; Dattaraja, H.S.; Davies, S.J.; Esufali, S.; et al. Assessing evidence for a pervasive alteration in tropical tree communities. PLoS Biol. 2008, 6, e45. [CrossRef] [PubMed]

19. Lewis, S.L.; Lopez-Gonzalez, G.; Sonke, B.; Affum-Baffoe, K.; Baker, T.R.; Ojo, L.O.; Phillips, O.L.; Reitsma, J.M.; White, L.; Comiskey, J.A.; et al. Increasing carbon storage in intact African tropical forests. Nature 2009, 457, 1003-1006. [CrossRef] [PubMed]

20. Röhling, S.; Dunger, K.; Kändler, G.; Klatt, S.; Riedel, T.; Stümer, W.; Brötz, J. Comparison of calculation methods for estimating annual carbon stock change in German forests under forest management in the German greenhouse gas inventory. Carbon Balance Manag. 2016, 11, 12. [CrossRef] [PubMed]

21. Pelletier, J.; Kirby, K.R.; Potvin, C. Significance of carbon stock uncertainties on emission reductions from deforestation and forest degradation in developing countries. For. Policy Econ. 2010, 24, 3-11. [CrossRef]

22. Coletta, V.; Menguzzato, G.; Pellicone, G.; Veltri, A.; Marziliano, P.A. Effect of thinning on above-ground biomass accumulation in a Douglas fir plantation in southern Italy. J. For. Res. 2016, 27, 1313-1320. [CrossRef]

23. Marziliano, P.A.; Coletta, V.; Menguzzato, G.; Nicolaci, A.; Pellicone, G.; Veltri, A. Effects of planting density on the distribution of biomass in a Douglas fir plantation in southern Italy. iForest 2015, 8, 368-376. [CrossRef]

24. Tabacchi, G.; Di Cosmo, L.; Gasparini, P. Aboveground tree volume and phytomass prediction equations for forest species in Italy. Eur. J. For. Res. 2011, 130, 911-934. [CrossRef]

25. Menguzzato, G.; Tabacchi, G. Prove di diradamento su Pseudotsuga menziesii in Calabria, Ambiente tavole di cubatura e della biomassa epigea. Ann. Ist. Sper. Selvic. 1986, 17, 255-293.

26. Jalkanen, A.; Mäkipää, R.; Stahl, G.; Lehtonen, A.; Peterson, H. Estimation of the biomass stock of trees in Sweden: Comparison of biomass equations and age-dependent biomass expansion factors. Ann. For. Sci. 2005, 62, 845-851. [CrossRef]

27. Schlesinger, W.H. Biogeochemistry: An Analysis of Global Change; Academic Press Inc.: London, UK; Harcourt Brace Jovanovich Publishers: San Diego, CA, USA, 1991; p. 443.

28. Mäkipää, R.; Peltoniemi, M.; Monni, S.; Palosuo, T.; Lehtonen, A.; Savolainen, I. Key sources of uncertainty in forest carbon inventories. In Proceedings of the EU Workshop on Uncertainties in Greenhouse Gas Inventories, Helsinki, Finland, 5-6 September 2005.

29. Zianis, D.; Muukkonen, P.; Mäkipää, R.; Mencuccini, M. Biomass and Stem Volume Equations for Tree Species in Europe. Silva Fennica Monographs 4. 2005. Available online: http:/ / www.metla.fi/silvafennica/ full/smf/smf004.pdf (accessed on 20 July 2017).

30. Clark, D.B.; Clark, D.A. Landscape-scale variation in forest structure and biomass in a tropical rain forest. For. Ecol. Manag. 2000, 137, 185-198. [CrossRef]

31. Keller, M.; Palace, M.; Hurtt, G. Biomass estimation in the Tapajos National Forest, Brazil: Examination of sampling and allometric uncertainties. For. Ecol. Manag. 2001, 154, 371-382. [CrossRef]

32. Chave, J.; Condit, R.; Aguilar, S.; Hernandez, A.; Lao, S.; Perez, R. Error propagation and scaling for tropical forest biomass estimates. Philos. Trans. R. Soc. Lond. B Biol. Sci. 2004, 359, 409-420. [CrossRef] [PubMed]

33. Chave, J.; Andalo, C.; Brown, S.; Cairns, M.A.; Chambers, J.Q.; Eamus, D.; Folster, H.; Fromard, F.; Higuchi, N.; Kira, T.; et al. Tree allometry and improved estimation of carbon stocks and balance in tropical forests. Oecologia 2005, 145, 87-99. [CrossRef] [PubMed]

34. Brown, S. Estimating Biomass and Biomass Change of Tropical Forests; Forestry Paper Food and Agriculture Organization: Rome, Italy, 1997; 94p.

35. Nogueira, E.M.; Fearnside, P.M.; Nelson, B.W.; Barbosa, R.I.; Keizer, E.W.H. Estimates of forest biomass in the Brazilian Amazon: New allometric equations and adjustments to biomass from wood-volume inventories. For. Ecol. Manag. 2008, 256, 1853-1867. [CrossRef]

36. Fehrmann, L.; Kleinn, C. General considerations about the use of allometric equations for biomass estimation on the example of Norway spruce in central Europe. For. Ecol. Manag. 2006, 236, 412-421. [CrossRef] 
37. Lehtonen, A.; Cienciala, E.; Tatarinov, F.; Makipaa, R. Uncertainty estimation of biomass expansion factors for Norway spruce in the Czech Republic. Ann. For. Sci. 2007, 64, 133-140.

38. Cienciala, E.; Hen̈̈lík, V.; Zatloukal, V. Assessment of carbon stock change in forests adopting IPCC LULUCF Good Practice Guidance in the Czech Republic. For. J. 2006, 52, 17-28.

(c) 2017 by the authors. Licensee MDPI, Basel, Switzerland. This article is an open access article distributed under the terms and conditions of the Creative Commons Attribution (CC BY) license (http:/ / creativecommons.org/licenses/by/4.0/). 